\title{
Records of rays of the genus Mobula (Chondrichthyes: Myliobatiformes: Myliobatidae) from the waters between Gabon and Angola (eastern tropical Atlantic)
}

\author{
CAROLINE R. WEIR ${ }^{1,2}$, BRUNO C.L. MACENA ${ }^{3}$ AND GIUSEPPE NOTARBARTOLO DI SCIARA ${ }^{4}$ \\ ${ }^{1}$ Ketos Ecology, 4 Compton Road, Kingsbridge, Devon, TQ7 2BP, UK, ${ }^{2}$ School of Biological Sciences (Zoology), University of \\ Aberdeen, Tillydrone Avenue, Aberdeen, Scotland, AB24 2TZ, UK, ${ }^{3}$ Departamento de Pesca e Aquicultura, Universidade \\ Federal Rural de Pernambuco, Rua Dom Manoel de Medeiros, s/n, 52171-030, Recife-PE, Brazil, ${ }^{4}$ Tethys Research Institute, \\ Viale GB Gadio 2, 20121 Milano, Italy
}

\begin{abstract}
The occurrence of the rays belonging to the genera Mobula (known collectively as the 'devil rays') and Manta is poorly documented in the eastern tropical Atlantic. Between August 2004 and September 2005, a total of 28 mobulid ray observations were recorded from geophysical survey vessels operating in the waters between Gabon and Angola. Water depth at the location of the sightings varied from 30 to $4000 \mathrm{~m}$, reflecting an occurrence in both neritic and oceanic habitat. While most animals were unidentified to species level, photographs taken during two sightings facilitated the identification of two separate species/ species groups of Mobula. The first individual, photographed at the surface in deep water offshore of northern Angola, was identified as belonging to the M. mobular/M. japanica species group, comprising two species that are very similar in appearance and which future evidence may reveal to represent a single species. The second animal, photographed off Pointe Noire in the Republic of the Congo, was identified as a bentfin devil ray (M. thurstoni). The previously documented southernmost records of these species in the eastern tropical Atlantic were in the Mediterranean Sea (M. mobular), Côte d'Ivoire (M. japanica) and Senegal (M. thurstoni). These observations therefore extend the known distribution ranges into the south-east Atlantic Ocean.
\end{abstract}

Keywords: Atlantic Ocean, Africa, geographical range, giant devil ray, Mobula mobular, spinetail mobula, Mobula japanica, bentfin devil ray, Mobula thurstoni

Submitted 12 January 2012; accepted 17 January 2012

\section{INTRロDUCTION}

The family Mobulidae consists of two genera, Mobula (known collectively as the 'devil rays') and Manta (Compagno \& Last, 1999). Nine species are recognized in the genus Mobula (Table 1), although it is currently unclear whether the giant devil ray Mobula mobular and the spinetail mobula $M$. japanica definitely represent separate species (Notarbartolo di Sciara, 1987). Until recently the genus Manta was considered to be monotypic (Marshall et al., 2006); however, two visually distinct species were recognized by Marshall et al. (2009) (Table 1). Due to similarities in their body size and external appearance, Manta and Mobula rays are often confused in the field (Marshall et al., 2006).

Notarbartolo di Sciara (1987) published a systematic review of the genus Mobula, based predominantly on

Corresponding author:

C.R. Weir

Email: Caroline.Weir@ketosecology.co.uk museum specimens and fisheries by-catch. Of the nine recognized species, three are circumglobal (M. japanica, Chilean devil ray $M$. tarapacana and bentfin devil ray $M$. thurstoni), two occur only in the Indo-Pacific region (pygmy devil ray $M$. eregoodootenkee and shortfin devil ray $M$. kuhlii), and the remainder appear to be endemic to particular areas comprising the eastern Pacific (Munk's devil ray M. munkiana), the Atlantic Ocean (lesser Guinean devil ray M. rochebrunei), the western Atlantic (lesser devil ray M. hypostoma) and the Mediterranean Sea (M. mobular) (Table 1) (Notarbartolo di Sciara, 1987; Cavanagh \& Gibson, 2007).

The marine mobulids of much of the eastern tropical Atlantic (ETA), which extends along the west coast of Africa from Mauritania to Angola (including the Gulf of Guinea), is poorly documented relative to many other geographical regions. Cadenat (1960) reviewed the mobulids occurring in the waters of the ETA based on specimens caught in local fisheries. That review indicated that four of the known species of Mobula occur within the ETA: (1) M. rochebrunei is documented from the coastal waters of Senegal (from where the holotype specimen MNHN A-9967 originates) and its distribution 
Table 1. Species of manta ray and devil ray belonging to the family Mobulidae. International Union for Conservation of Nature (IUCN, 2010) status is defined as: DD (Data Deficient); NT (Near Threatened); VU (Vulnerable); and EN (Endangered).

\begin{tabular}{|c|c|c|c|c|}
\hline Species & English name & Authority & IUCN status & Distribution \\
\hline \multicolumn{5}{|l|}{ Genus Manta } \\
\hline Manta alfredi & Inshore manta ray & Krefft, 1868 & - & $\begin{array}{l}\text { Widely distributed in (particularly inshore) tropical, } \\
\text { subtropical and temperate waters worldwide } \\
\text { (Marshall et al., 2009) }\end{array}$ \\
\hline Manta birostris & Giant manta ray & Donndorff, 1798 & NT & $\begin{array}{l}\text { Widely distributed in tropical, subtropical and } \\
\text { temperate waters worldwide (Marshall et al., 2006, } \\
\text { 2009) }\end{array}$ \\
\hline \multicolumn{5}{|l|}{ Genus Mobula } \\
\hline $\begin{array}{l}\text { Mobula } \\
\text { eregoodootenkee }\end{array}$ & Pygmy devil ray & Bleeker, 1859 & NT & $\begin{array}{l}\text { Tropical Indo-West Pacific Ocean and northern } \\
\text { Indian Ocean (IUCN, 2010) }\end{array}$ \\
\hline $\begin{array}{l}\text { Mobula } \\
\text { hypostoma }\end{array}$ & Lesser devil ray & Bancroft, 1831 & $\mathrm{DD}$ & $\begin{array}{l}\text { Endemic to the western Atlantic, from North } \\
\text { Carolina (USA) to northern Argentina (IUCN, } \\
\text { 2010) }\end{array}$ \\
\hline Mobula japanica & Spinetail devil ray & Müller \& Henle, 1841 & NT & $\begin{array}{l}\text { Probably circumglobal in all warm temperate and } \\
\text { tropical seas (IUCN, 2010) }\end{array}$ \\
\hline Mobula kuhlii & Shortfin devil ray & Müller \& Henle, 1841 & $\mathrm{DD}$ & $\begin{array}{l}\text { Indian Ocean and western central Pacific (IUCN, } \\
\text { 2010) }\end{array}$ \\
\hline Mobula mobular & Giant devil ray & Bonnaterre, 1788 & EN & $\begin{array}{l}\text { Mediterranean Sea. Possibly occurs also in the nearby } \\
\text { North Atlantic from Portugal south to Senegal } \\
\text { (however, uncertain due to potential confusion } \\
\text { with M. japanica) (Notarbartolo di Sciara et al., } \\
\text { 2006) }\end{array}$ \\
\hline Mobula munkiana & Munk's devil ray & $\begin{array}{l}\text { Notarbartolo-di-Sciara, } \\
\quad 1987\end{array}$ & NT & $\begin{array}{l}\text { Endemic to the tropical eastern Pacific Ocean } \\
\text { including the Gulf of California } \\
\text { (Notarbartolo-di-Sciara, 1987; IUCN, 2010) }\end{array}$ \\
\hline $\begin{array}{l}\text { Mobula } \\
\text { rochebrunei }\end{array}$ & Lesser Guinean devil ray & Vaillant, 1879 & VU & $\begin{array}{l}\text { Atlantic Ocean from Mauritania to Angola in the east } \\
\text { and from Brazil in the west (IUCN, 2010) }\end{array}$ \\
\hline $\begin{array}{l}\text { Mobula } \\
\text { tarapacana }\end{array}$ & Chilean devil ray & Philippi, 1892 & $\mathrm{DD}$ & $\begin{array}{l}\text { Probably circumglobal in temperate and tropical } \\
\text { waters (IUCN, 2010) }\end{array}$ \\
\hline Mobula thurstoni & Bentfin devil ray & Lloyd, 1908 & NT & $\begin{array}{l}\text { Probably circumglobal in all temperate and tropical } \\
\text { seas (IUCN, 2010) }\end{array}$ \\
\hline
\end{tabular}

probably includes the Gulf of Guinea and other parts of the ETA (Notarbartolo di Sciara, 1987); (2) M. lucasana (a junior synonym of M. thurstoni; Notarbartolo di Sciara, 1987) has been documented from Senegal (Cadenat, 1958a, b, 1960; Blache et al., 1970); (3) M. rancureli (a junior synonym of $M$. japanica; Notarbartolo di Sciara, 1987) has been documented from Abidjan in Côte d'Ivoire (holotype of $M$. rancureli: MNHN 1965-146; Cadenat, 1959); and (4) M. coilloti (a junior synonym of $M$. tarapacana; Notarbartolo di Sciara, 1987 ) is also known from Abidjan in Côte d'Ivoire (holotype of $M$. coilloti: MNHN 1965-144; Cadenat \& Rancurel, 1960). Consequently, existing knowledge about mobulids in the ETA is limited mostly to the waters off Senegal and Côte d'Ivoire in the northern hemisphere. The same four species, and additionally $M$. hypostoma, have also been recorded in the tropical western Atlantic, off Venezuela and/or Brazil (Notarbartolo di Sciara \& Hillyer, 1989; Gadig \& Sampaio, 2002; Gadig et al., 2003). Mobula japanica, M. tarapacana and $M$. thurstoni have been recorded from the central Atlantic in the Saint Peter and Saint Paul Archipelago (Vaske-Jr et al., 2005). A further species, M. mobular, inhabits the Mediterranean Sea but records suggest that it might also occur in the eastern Atlantic (Notarbartolo di Sciara, 1987; Castro et al., 2000). Mobula japanica, M. mobular and M. tarapacana have been taken as by-catch in Spanish tuna purseseine fisheries in the North Atlantic (Serralde et al., 2007).

This paper describes the location of mobulid ray sightings in the waters between Gabon and Angola in the south-east
Atlantic, and discusses the identification of two Mobula ray species that were photographed off the Republic of the Congo and Angola respectively. This information adds to current knowledge about the geographical distribution range and at-sea occurrence of this genus.

\section{MATERIALS ANDMETHDDS}

Between August 2004 and September 2005, data on marine fauna were collected concurrently with two consecutive geophysical seismic surveys in ETA waters. Dedicated watches for cetaceans and marine turtles were carried out by a single observer using the naked eye and $10 \times 42$ binoculars throughout daylight hours and in all weather conditions on each day at sea (see Weir, 2007 for further information on the platforms, cetacean survey methods and the distribution of survey effort). Most survey effort was located off northern Angola and the Democratic Republic of the Congo. However, data were also collected during return transits to ports in Gabon and the Republic of the Congo.

Although not the primary focus of the survey work, information was collected on large fish species (e.g. sharks, rays and ocean sunfish Mola mola) observed at the surface. These data included the time of the observation (which was linked to positional information via the cetacean survey effort log), species identification, number of animals, distance from the survey platform, behaviour and Beaufort sea state. When conditions 
permitted, animals were photographed in the field to confirm the species identification using a Canon SLR camera and a 100-400 mm Canon zoom lens. However, the nature of the survey and the brevity and distance of most sightings meant that opportunities for photographing ray species were rare.

Water depths were calculated for ray observations using the Arcview 3.2 Geographic Information System (GIS). A triangular integrated network continuous surface was created from GEBCO Digital Atlas 2003 contour data, and a depth value for each sighting extracted using the interpolated midpoint depth in $1 \mathrm{~km}^{2}$ resolution bathymetric grids.

\section{RESULTS AND DISCUSSION}

Between August 2004 and September 2005, a total of 28 Mobulid ray observations were recorded by one of the authors $(\mathrm{CW})$ in the waters between Gabon and Angola (Figure 1). All of the observed animals were estimated to have: (1) large body size with a disc width (greatest dimension between the outermost tips of the pectoral fins) of between $1 \mathrm{~m}$ and $3 \mathrm{~m}$; (2) long and curved pectoral fins; and (3) a dark blue-grey dorsal coloration with paler supra-branchial shoulder patches (variable). A white ventral surface, white cephalic fins and a thin wire-like tail were visible in leaping and close subsurface animals. Because of these combined features, these rays were identified as belonging to the Manta and/or Mobula genera.

Most observations $(\mathrm{N}=25 ; 89.3 \%)$ comprised single animals. On three occasions pairs of rays were recorded; two of these involved leaping rays and in one instance two large rays (estimated $3 \mathrm{~m}$ disc width) were seen chasing one another below the water. Most records $(\mathrm{N}=20 ; 71.4 \%)$ were of rays swimming at, or just below, the surface, with the tips of their pectoral fins usually breaking the surface.
Eight records comprised leaping individuals, where animals were somersaulting backwards (often on multiple occasions).

Reflecting the spatial distribution of the survey work (Weir, $2007)$, the majority $(\mathrm{N}=21$ ) of observations were recorded in the waters off northern Angola and the Democratic Republic of the Congo. Sightings also occurred during transits through Gabonese waters $(\mathrm{N}=1)$, and both offshore $(\mathrm{N}=1)$ and close to the coast (off Pointe Noire) $(\mathrm{N}=5)$ in the waters of the Republic of the Congo. The water depth at the location of the sightings varied from 30 to $4000 \mathrm{~m}$, with most $(\mathrm{N}=$ 19) occurring at depths greater than $1000 \mathrm{~m}$ (where the majority of survey effort was located; Weir, 2007).

Although most sightings could not be identified to species level, photographic evidence for the occurrence of two Mobula species was obtained.

\section{Sighting 1: M. japanica/M. mobular}

\section{LOCATION AND BEHAVIOUR}

On 11 August 2004, a single Mobula ray was observed and photographed approximately $160 \mathrm{~km}$ west of Soyo in northern Angola (06 $18.17^{\prime} \mathrm{S} 010^{\circ} 50.04^{\prime} \mathrm{E}$; Figure 1). Water depth was $1725 \mathrm{~m}$ and Beaufort sea state was o. During the sighting the ray swam slowly past the bow of the vessel (subsurface throughout) and a series of four photographs was taken (Figure 2).

\section{IDENTIFICATION}

One of the key features of the animal photographed in Figure 2 was the white apex of its dorsal fin. Only three Mobula species are known to exhibit the morphological characteristic of a white dorsal fin tip: M. mobular, M. japanica and $M$. thurstoni. The first two of these species exhibit a very long tail; the tail length of some adult $M$. japanica may equal or exceed the disc width, and the tail length of
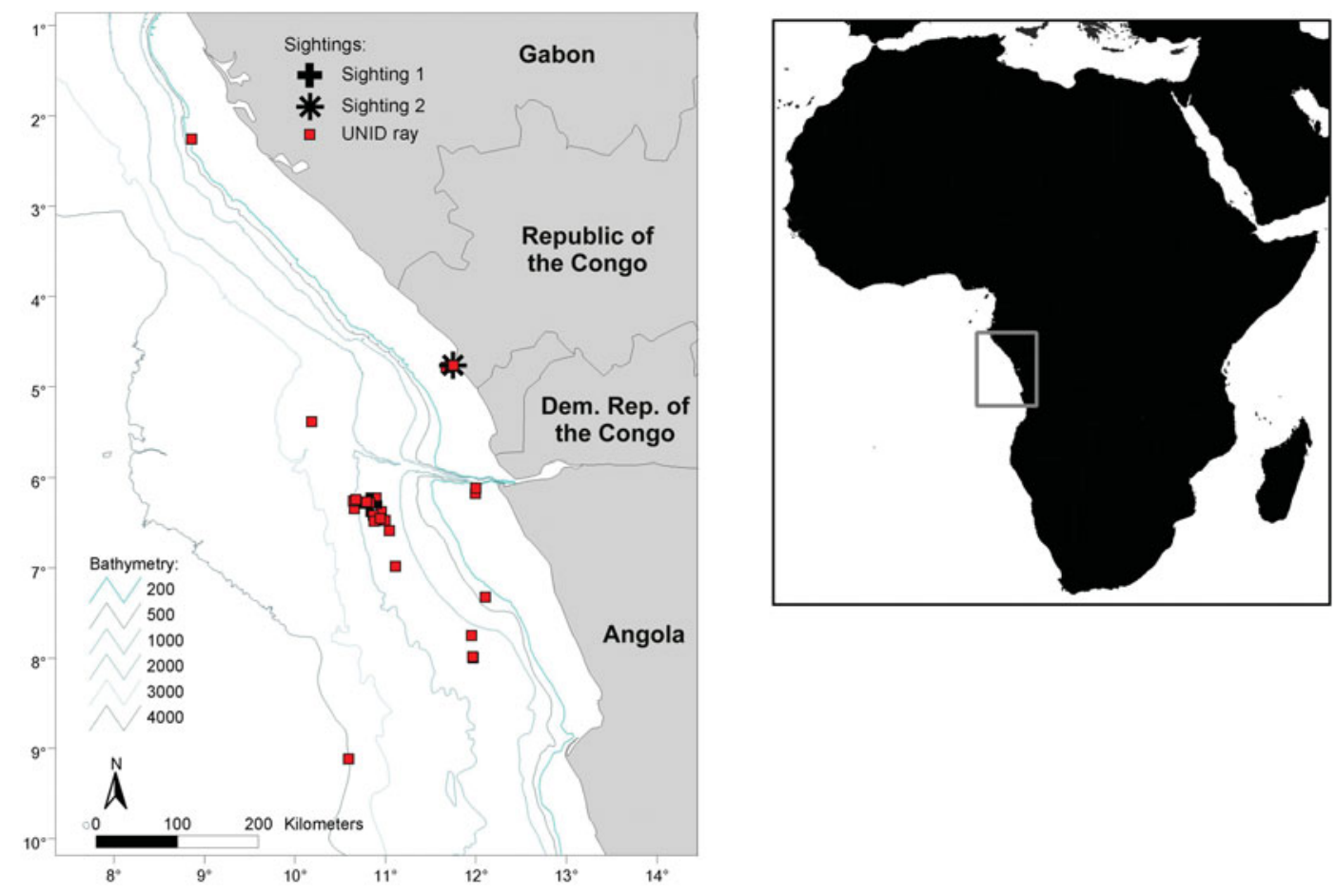

Fig. 1. Location of observations $(\mathrm{N}=28)$ of mobulid rays in the waters between Gabon and Angola, August 2004 to September 2005. 


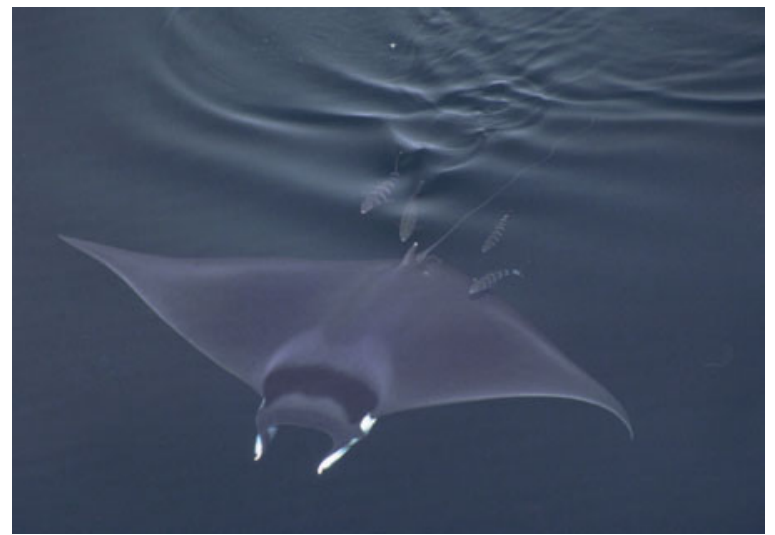

Fig. 2. Mobula ray identified as either M. mobular or M. japanica, photographed in the waters located off the Angola/Democratic Republic of the Congo border on 11 August 2004.

M. mobular is also described as being 'very long' (Notarbartolo di Sciara, 1987). In contrast, the tail of M. thurstoni is approximately $60 \%$ of the disc width (Notarbartolo di Sciara, 1987). The animal photographed in Figure 2 exhibits a tail length at least equal to disc width, and is consequently considered to belong to the $M$. japanica/M. mobular species group.

Mobula japanica and M. mobular are very similar in external appearance. Notarbartolo di Sciara et al. (2006) noted that 'expert examination is needed to distinguish M. mobular from M. japanica', and Notarbartolo di Sciara (1987) reported that the two species may be possibly distinguished by their maximum size (M. mobular becoming larger), and morphometrics ( $M$. mobular reaching greater disc width relative to the rest of the body). Observing these relative features in live animals at sea is not possible. It should also be noted that the validity of separate species status for M. mobular and $M$. japanica has been questioned, with the overlap in their morphological features potentially indicative of single species status (Notarbartolo di Sciara, 1987).

Further specimens of both species in the eastern Atlantic are required for morphological, and possibly genetic, analysis to clarify their status. Consequently, the animal photographed in Figure 2 was identified as belonging to either M. japanica or M. mobular, pending clarification on the taxonomic status of the M. japanica/mobular species group.

\section{RELEVANCE TO KNOWN DISTRIBUTION}

Mobula japanica is considered likely to be circumtropical, although most documented records to date are from the Pacific Ocean (Notarbartolo di Sciara, 1987). However, Cadenat (1959) described a $M$. japanica from Abidjan in Côte d'Ivoire, confirming its occurrence in the ETA. Mobula mobular is only verified to occur in the Mediterranean, although its distribution may extend to the eastern North Atlantic from Portugal south to Senegal, where unidentified Mobula specimens with a caudal spine have also been recorded (Notarbartolo di Sciara, 1987; Notarbartolo di Sciara et al., 2006). Confusion between $M$. mobular and M. japanica limits current understanding of the respective distribution ranges of these species in the eastern Atlantic (Notarbartolo di Sciara et al., 2006).

There appear to be no confirmed records of M. japanica or M. mobular in the eastern Atlantic to the south of Cadenat's (1959) record of $M$. japanica from Côte d'Ivoire.
Consequently, the sighting reported here would extend the known distribution range of either of these species southwards to the waters off northern Angola in the south-east Atlantic Ocean. If future studies indicate that $M$. japanica and M. mobular actually represent a single species, then northern Angola can be considered the southernmost limit documented for that species at present.

\section{Sighting 2: Mobula thurstoni}

\section{LOCATION AND BEHAVIOUR}

On 6 September 2005, five sightings of somersaulting individuals or pairs of rays were recorded on the approach to Pointe Noire in the Republic of the Congo. The second of these sightings comprised a single Mobula ray which was observed to somersault several times approximately $10 \mathrm{~km}$ west of Pointe Noire $\left(04^{\circ} 46.12^{\prime} \mathrm{S} 011^{\circ} 44.77^{\prime} \mathrm{E}\right.$; Figure 1) in $29 \mathrm{~m}$ water depth. Beaufort sea state was 4 . A series of three photographs was taken during one of the ray's somersaults (Figure 3).
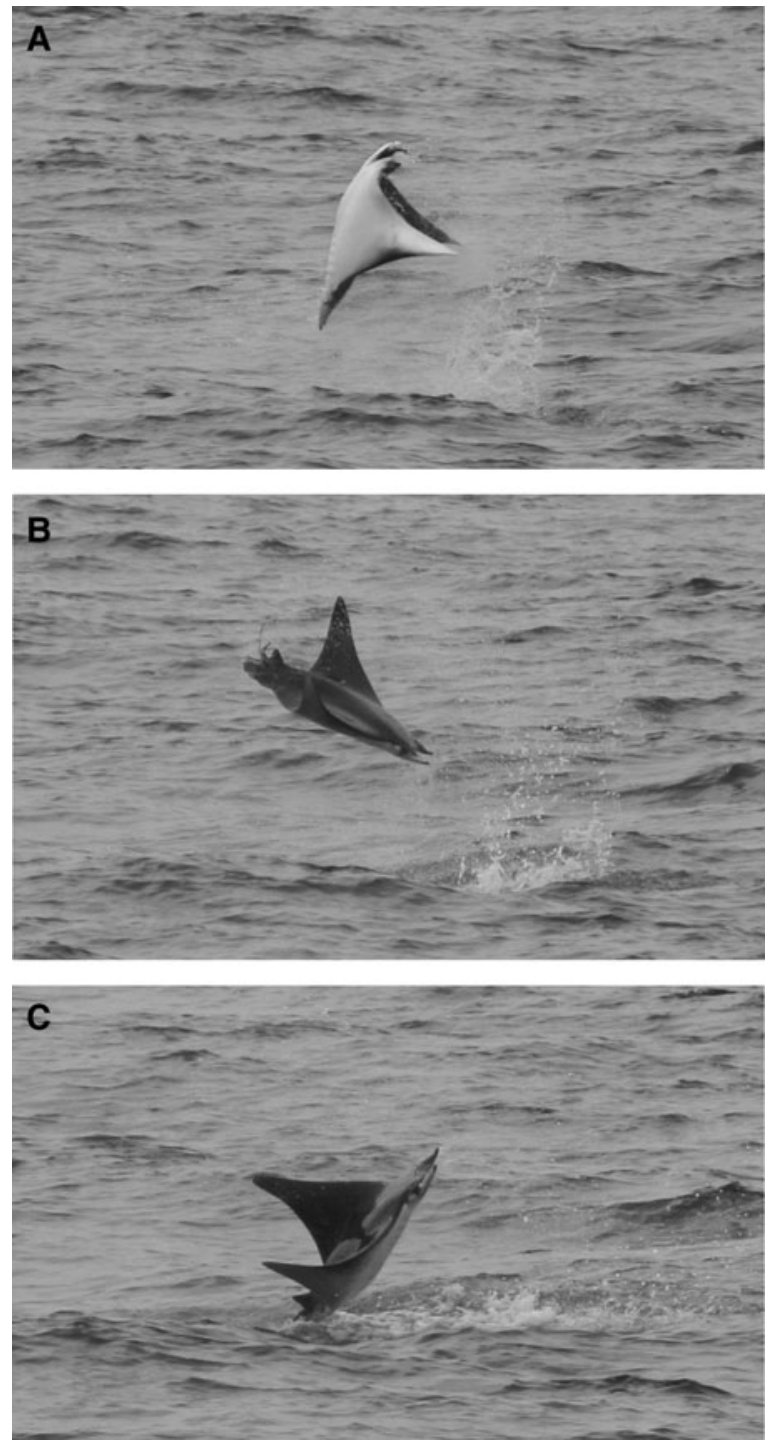

Fig. 3. Somersaulting ray (consecutive images of a single leap labelled as A-C) identified as Mobula thurstoni, photographed off Pointe Noire, Republic of the Congo, on 6 September 2005. 


\section{IDENTIFICATION}

The ray appeared to be dark blue in coloration on its dorsal surface, with a mostly white ventral surface. It was estimated to be approximately $1.2 \mathrm{~m}$ in disc width. Two key features are visible in Figure 3: (1) the sigmoidal shape of the anterior margin of the pectoral fins; and (2) a conspicuous area of dark shading on the ventral side of the pectoral fin, near the centre of the anterior margin (Figure $3 \mathrm{~A}$ ). The prominent double curvature of the anterior margin of the pectoral fin is distinctive to Mobula thurstoni (Cadenat, 1958a; Notarbartolo di Sciara, 1987; Gadig et al., 2003), and distinguishes it conclusively from all other Mobula species. Furthermore, M. thurstoni is known to exhibit a dark rim along the anterior margin of the ventral side of the pectoral fins, which widens around the concave turning point (Cadenat, 1958a; Notarbartolo di Sciara, 1987). Consequently, both of these features support M. thurstoni as the identification of this ray.

The behaviour of this individual also provides information regarding its potential identification, since certain species of Mobula are more prone to display leaping behaviour than others. Mobula thurstoni is one species known to frequently leap from the water in somersaults (Notarbartolo di Sciara, 1988).

\section{RELEVANCE TO KNOWN DISTRIBUTION}

Mobula thurstoni is likely to be circumtropical in distribution (Notarbartolo di Sciara, 1987). The species has been previously recorded in the ETA region from several specimens landed at Goree and Dakar in Senegal (Cadenat, 1958a, 1960; Blache et al., 1970).

There appear to be no confirmed records of $M$. thurstoni to the south of Senegal in the ETA, and consequently the record presented here extends the documented distribution range of the species considerably southwards to the waters of the Republic of the Congo.

\section{CONCLUSIONS}

The habits and ecology of mobulid rays worldwide are very poorly documented (Notarbartolo di Sciara \& Hillyer, 1989), and this is particularly the case in the ETA where little research on these species has been carried out to date. The observations reported here expand on the specimen records reviewed by Cadenat (1960) by providing the first information on the at-sea distribution of mobulid rays in the region, and extending the known distribution ranges of both $M$. mobular/M. japanica and of $M$. thurstoni considerably southwards from previous records to include regions of the southeast Atlantic. The data here, together with Cadenat (1960), indicate a widespread occurrence of mobulids in the ETA, including both neritic and oceanic waters.

Coloration patterns and external morphology were used to identify the two species photographed in the ETA, based on available knowledge of these features for the nine species described by Notarbartolo di Sciara (1987). However, for some species those descriptions were based on small sample sizes (single specimens in some instances) and often used ancient museum specimens, which may not accurately reflect the coloration patterns and morphological details of the living animals (Notarbartolo di Sciara, 1987). In particular, coloration patterns, such as pale markings, may quickly fade in dead and long-preserved specimens. Furthermore, on a global basis the use of coloration patterns to identify mobulid species might be limited by the variation that occurs between geographical populations, and between individuals and ages (Notarbartolo di Sciara \& Hillyer, 1989; Marshall et al., 2009). Consequently, when the external appearance of a particular species has been described primarily from specimens obtained from other ocean regions such as the Pacific, it is unclear whether the same features are also consistent in the ETA. For example, Notarbartolo di Sciara (1987) reported that $M$. thurstoni from the East Pacific exhibited a dark-greenish oval patch on the ventral side of the pectoral fin, which was absent in specimens from the Indo-West Pacific and Atlantic regions. While caution is therefore necessary when using external appearance alone to identify Mobula rays, the combination of features described for the two individuals photographed in the ETA, and the known presence of these species from previous records in the northern hemisphere ETA (Cadenat, 1958a, b, 1959, 1960), provide good support for the identifications made.

While these records provide initial information on new species range states and the at-sea distribution of Mobula thurstoni and M. mobular/M. japanica, knowledge about mobulids in the ETA remains very poor. Given the 'near threatened' (M. japanica and M. thurstoni) or 'endangered' (M. mobular) IUCN conservation status (IUCN, 2010) of these species (Table 1), more information is required to fully document their respective ecology, distribution range and status in the ETA. Considerable by-catch and directed takes of mobulid rays occurs in some artisanal and commercial fisheries worldwide (e.g. in gill-nets and by harpoon in Indonesia; White et al., 2006), and the limited evidence available suggests that by-catch also occurs in the ETA (e.g. in trawler fisheries off Mauritania; Zeeberg et al., 2006). Monitoring of landings at fishing ports is likely to be one viable method of obtaining specimens and greatly improving knowledge about these, and other, mobulid species in the ETA region.

\section{ACKNDWLEDGEMENTS}

BP Angola and their partners in Blocks 18 and 31 sponsored the cetacean survey work, and provided permission for the production of this publication. Thanks to the captains and crews of the 'Geco Titan' and the 'Sea Trident' for their hospitality during the survey work. The comments of three anonymous referees and the Executive Editor improved the content of this manuscript.

\section{REFERENCES}

Blache J., Cadenat J. and Staugh A. (1970) Clés de determination des poissons de mer signals dans l'Atlantique oriental (entre le $20^{\circ} \mathrm{N}$ et le $15^{\circ}$ S). Faune Tropicale, Paris 18, 1-479.

Cadenat J. (1958a) Notes d'ichtyologie ouest-africaine. XVIII. Un 'Diable de mer' du Pacifique est, Mobula lucasana Beebe \& Tee-Van 1938, sur les côtes du Sénégal. Bulletin de l'Institut Français d'Afrique Noire 20A, $1427-1433$.

Cadenat J. (1958b) Les diables de mer. Notes Africaines 80, 116-120.

Cadenat J. (1959) Notes d'ichtyologie ouest-africaine. XXV. Déscription d'une Mobula de grande taille, a aiguillon caudal, de Côte d'Ivoire: 
Mobula rancureli, sp. nov. Bulletin de l'Institut Français d'Afrique Noire 21A, 1326-1331.

Cadenat J. (1960) Notes d'ichtyologie ouest-africaine. XXIX. Les Mobulidae de la côte occidentale d'Afrique. Bulletin de l'Institut Français d'Afrique Noire 22A, 1053-1084.

Cadenat J. and Rancurel P. (1960) Notes d'ichtyologie ouest-africaine. XXVI. Description d'une nouvelle espèce de Mobulidae de la Côte d'Ivoire: Mobula coilloti. Bulletin de l'Institut Français d'Afrique Noire 22A, 283-288.

Castro J., de la Serna J.M., Macías D. and Mejuto J. (2000) Estimaciones científicas preliminares de los desembarcos de especies asociadas realizados por la flota Española de palangre de superficie en 1997 y 1998. International Commission for the Conservation of Atlantic Tunas, Collective Volume of Scientific Papers 51, 1882-1893.

Cavanagh R.D. and Gibson C. (2007) Overview of the conservation status of cartilaginous fishes (Chondrichthyans) in the Mediterranean Sea. Gland, Switzerland, and Malaga, Spain: International Union for Conservation of Nature, $42 \mathrm{pp}$.

Compagno L.J.V. and Last P.R. (1999) Mobulidae. In Carpenter K.E. and Niem V.H. (eds) FAO Species Identification Guide for Fishery Purposes. The living marine resources of the western central Pacific. Volume 3. Batoid fishes, Chimaeras and bony fishes. Part 1. (Elopidae to Linophyrnidae). FAO: Rome, pp. 1524-1529.

Gadig O.B.F., Namora R.C. and Motta F.S. (2003) Occurrence of the bentfin devil ray, Mobula thurstoni (Chondrichthyes: Mobulidae), in the western Atlantic. Journal of the Marine Biological Association of the United Kingdom 83, 869-870.

Gadig O.B.F. and Sampaio C.L.S. (2002) Ocorrência de Mobula japanica (Müller \& Henle, 1841) no Atlântico ocidental e Mobula tarapacana (Philippi, 1892) em águas brasileiras, com comentários sobre a diversidade de raias-manta do Brasil (Chondrichthyes, Mobulidae). Arquivos de Ciências do Mar 35, 33-37.

IUCN (2010) International Union for Conservation of Nature Red List of Threatened Species. Version 2010.4. <www.iucnredlist.org> (accessed 24 April 2011).

Marshall A., Ishihara H., Dudley S.F.J., Clark T.B., Jorgensen S., Smith W.D. and Bizzarro J.J. (2006) Manta birostris. In IUCN, 2010. International Union for Conservation of Nature Red List of Threatened Species. Version 2010.4. <www.iucnredlist.org> (accessed 24 April 2011).

Marshall A.D., Compagno L.J.V. and Bennett M.B. (2009) Redescription of the genus Manta with resurrection of Manta alfredi
(Krefft, 1868) (Chondrichthyes; Myliobatoidei; Mobulidae). Zootaxa 2301, 1-28.

Notarbartolo di Sciara G. (1987) A revisionary study of the genus Mobula Rafinesque, 1810 (Chondrichthyes: Mobulidae), with the description of a new species. Zoological Journal of the Linnaean Society, London 91, 1-91.

Notarbartolo di Sciara G. (1988) Natural history of the rays of the genus Mobula in the Gulf of California. Fishery Bulletin 86, 45-66.

Notarbartolo di Sciara G. and Hillyer E.V. (1989) Mobulid rays off eastern Venezuela. Copeia 1989, 607-614.

Notarbartolo di Sciara G., Serena F. and Mancusi C. (2006) Mobula mobular. In IUCN, 2010. International Union for Conservation of Nature Red List of Threatened Species. Version 2010.4. <www. iucnredlist.org $>$ (accessed 24 April 2011).

Serralde R., de Molina A.D., Santana J.C., de Molina R.D. and Ariz J. (2007) Estimación de los descartes y de las capturas de especies accesorias en la pesquería Española de cerco de túnidos tropicales en el Océano Atlántico, entre 2001 y 2006. International Commission for the Conservation of Atlantic Tunas, Collective Volume of Scientific Papers 60, 2130-2139.

Vaske-Jr T., Lessa R.P., Nóbrega M.F., Montealegre-Quijano S., Santana F.M. and Bezerra-Jr J.L. (2005) A checklist of fishes from Saint Peter and Saint Paul Archipelago, Brazil. Journal of Applied Ichthyology 21, 75-79.

Weir C.R. (2007) Occurrence and distribution of cetaceans off northern Angola, 2004/05. Journal of Cetacean Research and Management 9, 225-239.

White W.T., Giles J., Dharmadi and Potter I.C. (2006) Data on the bycatch fishery and reproductive biology of mobulid rays (Myliobatiformes) in Indonesia. Fisheries Research 82, 65-73.

and

Zeeberg J., Corten A. and de Graaf E. (2006) Bycatch and release of pelagic megafauna in industrial trawler fisheries off Northwest Africa. Fisheries Research 78, 186-195.

\section{Correspondence should be addressed to:}

C. Weir

Ketos Ecology, 4 Compton Road

Kingsbridge, Devon

TQ7 2BP, UK

email: Caroline.Weir@ketosecology.co.uk 